\title{
METAFORA KONSEPTUAL HIDUP ADALAH PERJALANAN DALAM TETRALOGI LASKAR PELANGI KARYA ANDREA HIRATA
}

\author{
(Sebuah Kajian Linguistik Kognitif) \\ Merry Lapasau ${ }^{1}$, Sulis Setiawati ${ }^{2}$, Apriani Riyanti ${ }^{3}$ \\ E-mail: mlapasau@gmail.com, sulis2310@yahoo.co.id, \\ aprianti.riyanti@binawan.ac.id \\ Universitas Indraprasta PGRI Jakarta ${ }^{1,2}$ \\ Universitas Binawan ${ }^{3}$
}

\begin{abstract}
Abstrak
Setiap budaya memahami hidup dengan caranya sendiri dan setiap bahasa mempunyai cara tersendiri dalam mengungkapkan makna hidup secara metaforis. Tujuan penelitian ini untuk mendeskripsikan metafora konseptual kehidupan adalah perjalanan dalam Tetralogi Laskar Pelangi (selanjutnya ditulis TLP) karya Andrea Hirata. Penelitian ini menggunakan metode deskriptif kualitatif dengan kerangka teoretis conceptual metaphor theory (CMT) dari Lakoff \& Johnson (1980/2003) dalam ranah kognitif linguistik. Hasil penelitian menunjukkan bahwa metafora konseptual kehidupan adalah perjalanan dalam TLP mempunyai domain sumber sebagai berikut: 1) arah hidup, 2) haluan hidup, 3) ekspedisi hidup, 4) jembatan, 5) labirin, 6) orientasi hidup, 7) tiket, dan 8) siklus. Dalam teori metafora kognitiv, analisis metafora memberikan jawaban atas pertanyaan tentang bagaimana kita membangun dunia dari pola-pola yang kita kenal. Melalui analisis metafora konseptual kehidupan adalah perjalanan, kita dapat memahami bagaimana masyarakat Melayu memaknai hidup seperti yang tertuang dalam TLP melalui karya Andrea Hirata, yaitu hidup haruslah dijalani sesuai dengan arah yang tepat, orientasi dan haluan yang benar, penuh petualangan (ekspedisi), berliku-liku (labirin, siklus) dan tidak selalu mudah (melalui jembatan, membeli tiket). Walaupun hidup tidak selalu mudah namun harus dijalani dengan sebaik-baiknya dengan berpedoman pada arahan yang tepat yang berlaku di masyarakat, hidup harus menghormati orangtua dan mengambil contoh dari perilaku baik orangtua, dan kita harus senantiasa berusaha hidup lebih baik dengan cara senantiasa memperbaiki diri sendiri.
\end{abstract}

Kata kunci: Metafora Konseptual hidup adalah perjalanan, CMT, Tetralogi Laskar Pelangi, Andrea Hirata 


\section{Pendahuluan}

Secara tradisional, ada beberapa ciri khas metafora yang sudah dikenal luas, yaitu: a) Metafora dipandang sebagai kiasan dekoratif semacam hiasan artistik yang digunakan untuk menciptakan beberapa efek khusus bagi pendengar atau pembaca, dan b) Metafora merupakan fenomena linguistik dan bukan fenomena bahasa konseptual (Lapasau et al., 2020). Selanjutnya Isgarjan \&Stankic (2015) menjelaskan bahwa persepsi dan pemahaman metafora tradisional berubah secara radikal ketika Lakoff dan Johnson (1980/2003) mengemukakan pendapat mereka bahwa metafora merupakan mekanisme kognitif fundamental dan intrinsik yang memungkinkan konseptualisasi konsep abstrak yang lebih efisien. Dengan demikian, konsep abstrak dapat tercermin dalam penggunaan bahasa sehari-hari dalam bentuk ekspresi metaforis yang mencerminkan metafora konseptual yang diberikan. Mereka berpendapat bahwa semua konsep, kecuali yang perseptual dan eksperiensial, sebenarnya bersifat metaforis, dan penggunaan bahasa sehari-hari penuh dengan ekspresi metaforis yang merupakan hasil pemikiran metaforis. Secara umum, ahli teori kognitif mengidentifikasi metafora sebagai proses pemetaan antara dua domain konseptual yang berbeda: domain target (konsep yang akan dijelaskan oleh metafora), dan domain sumber (konsep yang digunakan untuk membuat konstruksi metaforis). Lakoff \& Johnson (1987) juga menyatakan bahwa perwujudan fisik dan penataan imajinatif kita dalam cara kita mengalami dan memahami realitas sangat penting dalam pemahaman kita tentang dunia. Pola berulang dari pengalaman tertentu dan struktur skema tertentu yang memberikan koherensi pada pengalaman kita disebut skema imej, misalnya wadah, jalur, pusatpinggiran, siklus, kekuatan penyeimbang, tautan, dan lain-lain.

Dengan mengacu pada skema kognitif basal, Lakoff dan Johnson (1987) menganggap bahwa penggunaan metafora bukanlah suatu kebetulan, tetapi mengacu pada pola berpikir, persepsi, komunikasi, dan tindakan yang konsisten dan terbagi secara sosial. Karya mereka masih menawarkan pengantar terbaik untuk topik tersebut bagi peneliti kualitatif, dan oleh karena itu masih direkomendasikan sebagai acuan teori meskipun terdapat perubahan dalam terminologi. 
Singkatnya, definisi standar dari metafora konseptual dapat diberikan sebagai berikut: Metafora konseptual adalah sekumpulan korespondensi, atau pemetaan sistematis antara dua domain pengalaman (Kövecses, 2017). Domain pengalaman direpresentasikan dalam pikiran sebagai konsep yang diberikan sebagai kerangka mental, atau model kognitif. Karenanya, kita berbicara tentang metafora konseptual. Kerangka sumber dan kerangka target dihubungkan oleh sekumpulan korespondensi konseptual, atau pemetaan. Jadi, dalam pandangan ini, metafora adalah sekumpulan korespondensi, atau pemetaan, antara elemen dua kerangka mental. Misalnya, sekumpulan korespondensi antara seorang pengelana dan orang yang menjalani hidup - cara pengelana bepergian dan cara hidup orang tersebut, tujuan yang ingin dicapai pengelana dan tujuan hidup orang tersebut, dan kondisi fisik serta rintangan di sepanjang jalan dan kesulitan yang dialami orang dalam hidup - semuanya terdiri dari serangkaian pemetaan yang membentuk metafora konseptual kehidupan adalah perjalanan (Kövecses, 2015). El-Sharif (2016) berpendapat bahwa kekuatan kognitif metafora dan cara kerjanya memungkinkan penulis suatu wacana membuat metaforanya lebih jelas dan persuasif dan menjadikan sesuatu hal baru menjadi lebih mudah dipahami. Menurut Xu (dalam Lapasau, et.al, 2020) pemahaman metafora melibatkan faktor kognitif dan sosial budaya. Dia menambahkan, metafora secara keseluruhan mencerminkan budaya penggunanya dan pemahaman terhadap sebuah ungkapan metafora sebagian besar ditentukan oleh penguasaan budaya. Karena itu, ia pun menegaskan bahwa faktor sosial dan kognitif memengaruhi interpretasi kita terhadap ungkapan metafora apa pun terutama terutama metafora baru.

Lebih lanjut, menurut Lakoff und Johnson (1980), metafora terjadi jika:

a) sebuah kata atau frase dalam arti sempit dalam konteks yang relevan dengan ekspresi tuturan memiliki lebih dari sekedar makna literal,

b) makna literal berasal dari area makna yang ringkas (area sumber),

c) dan pada saat yang sama dipindahkan ke area kedua yang seringkali lebih abstrak (area target). 
Perkembangan terkini dalam bidang linguistik kognitif telah memunculkan minat baru pada penelitian metafora seperti dari perspektif analisis wacana surat kabar (Boeynaems et al., 2017), metafora dalam bahasa Inggris bisnis di bidang linguistik kontrastif dan terapan (Grygiel, 2015; Smit, 2010), ragam bahasa Inggris yang dituturkan di Afrika Selatan (Naicker, 2019); metafora dalam sastra (Culea \& Suciu, 2019; Fludernik, 2011; Lapasau et al., 2020), metafora dalam komunikasi media (Kövecses, 2018), studi budaya kontrastif (Hamdi, 2016; Yu, 2017), metafora dalam wacana meditasi (Antonio- José Silvestre-López, 2020), didaktik metafora (El Sharif, 2016), metafora dalam kajian penerjemahan (Oliynyk, 2014; Burmakova \& Marugina, 2014), etc. Benczes \& Ságvári (2018) mengkaji metafora konseptual kehidupan yang dipahami kaum muda Hongaria dengan hasil sebagai berikut: Pertama, metafora yang diidentifikasi merupakan karakter umum dan tidak ada konseptualisasi negatif yang umum muncul. Para remaja Hongaria mengonsep kehidupan terutama sebagai permainan, makanan, perjalanan, tantangan, tanaman, dan rollercoaster. Kedua, faktor sosial, jenis dan lokasi sekolah, status sosial ekonomi dan konsumsi media dapat berpengaruh pada pemilihan domain sumber, sehingga mengurangi pentingnya sejarah budaya dalam membentuk konseptualisasi kehidupan metaforis. Ketiga, faktor-faktor sosial memengaruhi kecenderungan keseluruhan penutur terhadap penggunaan ungapan metaforis. Sedangkan menurut Lakoff and Turner (1989) dan Kövecses (2010), konseptualisasi kehidupan adalah sebagai berikut: kehidupan adalah perjalanan, permainan, bangunan, beban, permainan, benda berharga, permainan dalam olahraga, cerita, perbudakan, api, cahaya, tanaman/ siklus kehidupan manusia sama dengan siklus kehidupan tanaman.

Di Indonesia, kajian metafora dalam bidang kognitif linguistik belum dapat dikatakan memadai secara kuantitas dan kualitas karena masih sangat banyak bidang yang belum dikaji dan berpeluang meningkatkan pemahaman tentang metafora konseptual. Oleh karena itu, penelitian ini diharapkan dapat menambah sumber rujukan tentang metafora konseptual di tanah air.

Kajian ini mengelaborasi berbagai ekspresi metafora yang mendasari konsep abstrak hidup dalam kerangka teori metafora konseptual. Penerapan teori ini 
menunjukkan bagaimana metafora konseptual efektif dalam menganalisis dunia konseptual kita dan meneliti aspek sosial dan budaya kognisi manusia.

\section{Metode Penelitian}

Metode yang digunakan dalam penelitian ini adalah studi pustaka dengan pendekatan kualitatif deskriptif. Menurut Denzin \& Lincoln (2011), penelitian kualitatif adalah penelitian yang menggunakan latar belakang alamiah dalam menginterpretasikan fenomena yang terjadi dengan memanfaatkan metode pengumpulan data, seperti wawancara, observasi, dan pemanfaatan dokumen. Semua metafora konseptual kehidupan adalah perjalanan dalamTLP digunakan sebagai korpus. Kami menggunakan prosedur MIP Grup Pragglejaz (metaphor identification procedures) untuk identifikasi metafora linguistik bila diperlukan dan untuk menjamin prosedur yang sama pada keseluruhan identifikasi metafora dalam TLP. MIP dijelaskan dalam langkah-langkah berikut:

1. Membaca seluruh teks untuk membangun pemahaman umum tentang maknanya.

2. Menentukan satuan leksikal dalam teks.

3. a. Untuk setiap unit leksikal dalam teks, tentukan artinya dalam konteks, yaitu bagaimana penerapannya pada entitas, relasi, atau atribut dalam situasi yang ditimbulkan oleh teks (makna kontekstual). Pertimbangkan apa yang muncul sebelum dan sesudah unit leksikal tersebut.

b. Untuk setiap unit leksikal, tentukan apakah ia memiliki makna kontemporer yang lebih mendasar dalam konteks lain daripada yang ada dalam konteks teks yang diberikan.

c. Jika unit leksikal tersebut memiliki makna kontemporer yang lebih mendasar dalam konteks lain daripada konteks yang diberikan, putuskan apakah makna kontekstual itu bertentangan dengan makna dasar tetapi dapat dipahami jika dibandingkan dengannya.

4. Jika ya, tandai unit leksikal tersebut sebagai metafora (Pragglejaz Group 2007:3).

Penelitian ini berfokus untuk menjawab pertanyaan sebagai berikut: 
1. Bagaimana domain sumber ungkapan metafora konseptual "hidup adalah perjalanan" dalam TLP?

2. Bagaimana nilai-nilai budaya masyarakat Indonesia yang tercermin melalui metafora kehidupan yang digunakan dalam TLP?

TLP dipilih sebagai objek penelitian karena tetralogi ini termasuk dalam best seller sehingga salah satu dari empat novelnya dengan judul yang sama, yaitu Laskar Pelangi telah diterjemahkan ke lebih dari 34 bahasa di dunia. Selain itu, TLP banyak memuat kisah inspiratif tentang kehidupan masyarakat marjinal dalam memperjuangkan pendidikan.

\section{Hasil Penelitian dan Pembahasan}

Metafora konseptual kehidupan adalah perjalanan dalam TLP dimanifstasikan dalam ungkapan yang berbeda-beda dengan domain sumber yang cukup beragam pula. Kehidupan adalah perjalanan dimanifestasikan paling banyak melalui domain sumber: 1) arah hidup, 2) haluan hidup, 3) ekspedisi hidup, 4) jembatan, 5) labirin, 6) orientasi hidup, 7) tiket, dan 8) siklus.

Berikut contoh dari TLP:

1a. Konsep menjalani hidup dengan gagasan memberi manfaat sebesar-besarnya kepada orang lain.

1b. Kalau nanti Tuk Bayan Tula akan memutar jalan hidupnya dan jalan hidup perempuan kecil yang sedang tersesat di rimba ini.

1c. Bahkan seringkali mereka yang tak kunjung menemukan identitas, menjalani jalan hidup sebagai orang lain.

1d. Hampa karena cinta dan kecewa pada masa depan, membuat A Kiong sempat menjalani hidup sebagai seorang Agnostik.

1e. Ia semacam budaya, semacam jalan hidup seperti sepak bola bagi rakyat Brasil. 
1f. Sungguh ganjil, perjalanan hidupku akhirnya membawaku dengan sendirinya kesini.

1g. Menjalani hidup sebagai orang lain.

Metafora konseptual dalam contoh nomer 1a-1g mengungkapkan bahwa hidup merupakan perjalanan yang harus ditempuh seseorang dalam artian netral, yaitu bisa jalan yang baik ataupun kurang baik. Keterangan bagaimana jalan yang akan ditempuh, belum terdapat dalam metafora konseptual itu sendiri tetapi ditambahkan dalam setiap kalimatnya.

Selain itu, terdapat metafora konseptual dengan domain sumber: haluan hidup dan arah hidup. Contoh dari TLP:

2. Dan pesan beliau yang berbunyi: jika ingin lulus ujian, buka buku, belajar! Ternyata menjadi kata-kata keramat yang mampu memutar haluan hidup mereka.

Haluan disini dimaknai sebagai sesuatu yang bisa mengarahkan dan menjadi pedoman hidup seseorang.

3. Dua kata yang menjawab kekeliruanku memaknai arah hidupku.

Metafora arah hidup bermakna arah atau jalan yang harus ditempuh seseorang selama perjalanan hidupnya. Dari dua contoh diatas, jelas sekali bahwa masyarakat Melayu mempunyai konsep pemikiran yang mendalam dalam memaknai hidup. Hidup bukan sekedar tanpa arah atau haluan, namun harus dipahami dan mempunyai pedoman agar tidak salah dalam berperilaku.

Domain sumber yang berikutnya adalah jembatan yang harus dilewati sebagai bagian dalam menempuh perjalanan hidup. Contoh dari TLP:

4. Dunia baginya hitam putih dan hidup adalah sekeping jembatan papan lurus yang harus dititi.

Metafora konseptual hidup adalah perjalanan dalam TLP selanjutnya membawa domain sumber labirin, siklus hidup, ekspedisi hidup, orientasi hidup, dan tiket dengan masing-masing contohnya sebagai berikut: 
5. Menyelami labirin lika liku hidup yang ujungnya tak dapat disangka.

Labirin merupakan jalan yang berliku-liku yang terkadang sangat susah mencari jalan keluar jika kita berada di dalamnya. Hal tersebut diangkat dalam TLP untuk menyiratkan perjalanan hidup seseorang yang harus mencari jalan keluar terbaik dalam permasalahan hidupnya.

6. Vibrasinya juga menggetarkan jiwa karena tenaga mistik sebuah ritual suci siklus hidup.

Siklus hidup seorang manusia dipengaruhi juga oleh berbagai keputusan yang diambilnya. Siklus hidup yang baik dapat terulang dan menjadi pedoman hidup untuk mengambil keputusan berikutnya. Demikian juga sebaliknya, siklus hidup yang kurang baik dapat terulang jika orang salah mengambil keputusan dalam hidupnya.

7. Jarak antara kedua matanya adalah bentangan titik zenit dan nadir ekspedisi hidupku.

Pemikiran orang Melayu dalam TLP menjelaskan bahwa hidup tidak hanya untuk dijalani semata apa adanya tapi juga sebagai suatu perjalanan yang membutuhkan petualangan seperti halnya sebuah ekspedisi yang biasanya terencana dengan baik.

8. Aku benar-benar bertekad mendapatkan beasiswa itu karena bagiku ia adalah tiket untuk meninggalkan hidupku yang terpuruk.

Kalimat contoh nomer 8 ini menggunakan kata tiket sebagai domain sumber untuk domain target hidup adalah perjalanan.Tiket merupakan sesuatu hal yang perlu dimiliki ketika seseorang berpergian dengan kendaraan umum. Disini kata tiket dimaknai sebagai sesuatu yang dapat memfasilitasi seseorang mendapatkan hidup yang lebih baik yaitu dengan mendapatkan beasiswa. 
9. Ayahnya adalah orientasi hidupnya.

Orientasi hidup seseorang dapat berupa perilaku orang lain yang dianggap dapat menjadi panutan. Dalam hal ini, seorang ayah dianggap sebagai jalan atau arah yang harus diikuti dalam menjalani hidup. Konsep ini merupakan konsep pemikiran orang Melayu yang masih dijaga kelestariannya yaitu bahwa menghormati orangtua dan mengambil contoh dari perilaku baik orangtua merupakan sesuatu yang menjadi budaya dalam masyarakat Melayu.

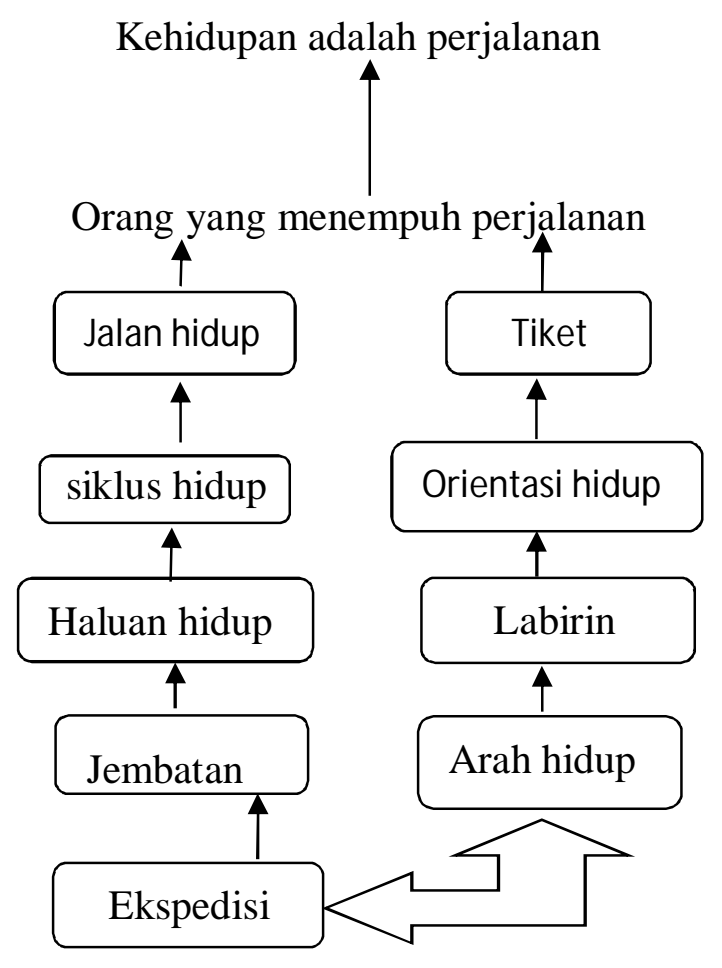

Gambar 1 domain sumber metafora konseptual kehidupan adalah perjalanan dalam TLP

\section{Simpulan}

Metafora konseptual kehidupan adalah perjalanan dalam TLP diungkapkan terutama melalui domain sumber: 1) Jalan hidup, 2) Siklus hidup, 3) Haluan hidup, 4) Jembatan, 5) Ekpedisi, 6) Tiket, 7) Orientasi hidup, 8) Labirin, dan 9) Arah hidup. Konsep pemikiran masyarakat Melayu yang menjadi budaya berakar turun menurun mereka tergambar jelas dalam metafora konseptual yang tertuang dalam TLP melalui pena Andrea Hirata. Konsep tersebut antara lain: hidup tidak 
selalu mudah namun harus dijalani dengan sebaik-baiknya dengan berpedoman pada arahan yang tepat dalam masyarakat, hidup harus menghormati orangtua dan mengambil contoh dari perilaku baik orangtua, kita harus senantiasa berusaha hidup lebih baik dengan cara memperbaiki diri sendiri. Hasil kajian ini sesuai dengan hasil penelitian sebelumnya yaitu bahwa konsep abstrak dapat tercermin dalam penggunaan bahasa sehari-hari dalam bentuk ekspresi metaforis yang mencerminkan metafora konseptual yang diberikan (Kövecses, 2017; El Sharif, 2016; Yu, 2017 ).

\section{Daftar Pustaka}

Benczes, Réka \& Ságvári, Bence. 2018. Where metaphors really come from:

Social Factors as Contextual Influence in Hungarian Teenagers' Metaphorical Conceptualizations of Life. Cognitive Linguistics. De Gruyter: Mouton. https://doi.org/10.1515/cog-2016-0139

Boeynaems, Amber et.al. 2017. The Impact of Conventional and Novel Metaphors in News on Issue Viewpoint. International Journal of Communication 11(2017), 2861-2879

Burmakova, Elena A. \& I. Marugina, Nadezda. 2014. Cognitive Approach to Metaphor Translation in Literary Discourse. Procedia - Social and Behavioral Sciences 154 (2014 ) 527 - 533. DOI:10. 1016/j.sbspro. 2014 .10 .180 .

Culea, Mihaela \& Suciu, Andreia-Irina. 2019. Understanding Shakespeare's Language and Thought through the Use of Similes and Metaphors. Elm vo Innovativ Texnologiyalar Jurnalı Nömrə 8, 2019. 8-25 DOI: 10.5782/26164418.8.2019.8.

Denzin, Norman. K \&. Lincoln, Yvonna. S. 2011. The Sage Handbook of Qualitative Research. Sage: USA

El-Sharif, Ahmad. 2016. A Theoretical Account on the Study of Metaphor in Didactic Discourse. Advances in Language and Literary Studies, vol. 7, no. 2, pp. 100-112

Fludernik, Monika. 2011. Beyond Cognitive Metaphor Theory: Perspectives on Literary Metaphor.

Grygiel, Marcin. 2015. The Conceptual Metaphor BUISNESS IS WAR in 
Business English. Im Wirkungsfeld der kontrastiven and angewandten Linguistik. In the Field of Contrastive and Applied Linguistics. Vol. 6. Ed. Wierzbicka, Mariola \& Lucyna Wille. Rzeszów: Wydawnictwo Uniwersytetu Rzeszowskiego. 65-78.

Hamdi, Sondes 2016. A Cognitive Study of Happiness Metaphors in English, Tunisian Arabic and Spanish. Arab World English Journal (AWEJ), vol. 6, no. $1,2016$.

I Made Rajeg. 2016. Metaphoric and Metonimic Conceptualization of Love in Indonesian. International Journal of Linguistics, Language and Culture (IJLLC). Vol 2 no 3, p 71-83. http:// dx. doi.org/10.21744/ijllc.v2i3.213

Izgarjan, Aleksandra \& Prodanović-Stankić, Diana. 2015. Approaches to Metaphor: Cognitive, Translation and Literature Studies Perspective. Faculty of Philosophy, Novi Sad. ISBN 978-86-6065-327-9. http://digitalna.ff.uns. ac.rs/sadrzaj/2015/978-86-6065-327-9

Kövecses, Zoltán. 2015. Where Metaphors Come From: Reconsidering Context in Metaphor. Oxford: Oxford University Press.

Kövecses, Zoltán. 2017. Conceptual Metaphor Theory. In: The Rouledge Handbook of Metaphor and Language. Ed: Zsófia Demjen \& Elene Semino. Oxon: Rouledge. p.1-27

Kövecses, Zoltán. 2018. Metaphor in Media Language and Cognition: A Perspective from Conceptual Metaphor theory. Lege artis. Language yesterday, today, tomorrow. The journal of University of SS Cyril and Methodius in Trnava. Warsaw: De Gruyter Open, 2018, III (1), June 2018, p. 124-141. DOI: 10.2478/lart-2018-0004 ISSN 2453-8035

Lakoff, George.\& Johnson, Mark. 1980. Metaphors We Live By. Chicago: Chicago University Press.

Lapasau, Merry et al., 2020. Conceptual Metaphors in Modern Indonesian Literature and Their Implication in Language Learning. Advances in Social Science, Education and Humanities Research, volume 512. Proceedings of the $1^{\text {st }}$ International Conference on Folklore, Language, Education and Exhibition (ICOFLEX 2019), p 235-240.

Naicker, Suren. 2019. An Analysis of Metaphorical Idioms in South African Indian English. Stellenbosch Papers in Linguistics Plus, Vol. 56, 2019, 1-12. doi: 10.5842/56-0-784. http://spilplus.journals.ac.za. 
Oliynyk, Tetyana. 2014. Metaphor Translation Methods. International Journal of Applied Science and Technology. Vol. 4 No. 1, p. 123-126.

Pragglejaz Group. 2007. MIP: A Method for Identifying Metaphorically Used Words in Discourse. Metaphor and Symbol. Vol. 22 (1), 1-39.

DOI:10.1080/10926480708336752

Silvestre-López, Antonio- José. 2020. Conceptual Metaphor in Meditation

Discourse: An Analysis of the Spiritual Perspective. GEMA Online Journal of Language Studies Volume 20 (1), February 2020 http://doi.org/10.17576/ gema-2020 -2001-03 eISSN: 2550-2131 ISSN: 1675-802135

Smit, Talita C. 2010. Conceptual Metaphor and Comprehension in Business Writing. Per Linguam 26 (2):20-321.

Yu, Ning. 2017. Life as Opera: A Cultural Metaphor in Chinese. In: F. Sharifian (ed.), Advances in Cultural Linguistics, Cultural Linguistics, Springer Nature Singapore Pte Ltd. 2017. DOI 10.1007/ 978-981-10-4056-6_4. P. 65-85. 